\title{
Patogenesis Gyrodactylus : Penentuan Derajat Infestasi, Pengamatan Gejala Klinis dan Patologi Insang Ikan Mas (Cyprinus carpio)
}

\section{Pathogenesis of Gyrodactylus : Degree of Infestation, Chlinical Symptoms, Gill Pathology of Goldfish (Cyprinus carpio)}

\author{
Putri Desi Wulansari $^{1 *}$, Gunanti Mahasri ${ }^{1}$ dan Koesnoto ${ }^{2}$ \\ ${ }^{1}$ Departemen Manajemen Kesehatan Ikan dan Budidaya Perairan, Fakultas Perikanan dan Kelautan, \\ Universitas Airlangga, Surabaya \\ ${ }^{2}$ Departemen Parasitologi Veteriner, Fakultas Kedokteran Hewan, Universitas Airlangga, Surabaya
}

*Correspondence :

putri.dw@fpk.unair.ac.id

Received : 2019-10-22

Accepted : 2019-12-17

Kata Kunci :

Gyrodactylus, Ikan Mas, Insang,

Patogenesis, Patologi

Keywords :

Gyrodactylus, Goldfish, Gill,

Pathogenesis, Pathology

\begin{abstract}
Abstrak
Penelitian ini bertujuan untuk mengetahui patogenesis infestasi Gyrodactylus yang menginfestasi insang ikan mas (Cyprinus carpio). Patogenesis diamati berdasarkan tingkat derajat infestasi, pengamatan gejala klinis dan patologi insang ikan mas (Cyprinus carpio). Sebanyak 1.440 ekor ikan mas terinfestasi Gyrodactylus diambil dan diamati perubahan patologi anatomi dan gejala klinisnya. Hasil pengamatan sampel menunjukkan pada derajat infestasi ringan dan berat, kerusakan yang ditimbulkan antara lain hiperplasia, hipertrofi dan hemoragi.
\end{abstract}

\begin{abstract}
This study aims to determine the pathogenesis of Gyrodactylus infestation, which infects the gills of carp (Cyprinus carpio). Pathogenesis is observed based on the degree of the infestation, observation of clinical symptoms, and pathology of carp (Cyprinus carpio) gill. A total of 1,440 goldfish infested with Gyrodactylus were taken and observed the anatomical pathology and its clinical symptoms. The results of sample observations showed that the degree of infestation was mild and severe; the damage caused was hyperplasia, hypertrophy, and hemorrhage, whereas healthy goldfish showed regular histopathological features of gills.
\end{abstract}

\section{PENDAHULUAN}

Studi tentang patogenesis agen parasit perlu dilakukan mengingat adannya infestasi parasit dapat menyebabkan dampak berbahaya bagi proses produksi dan semakin banyak ditemukannya kasus penyakit ikan (Molnár et al., 2019), juga sebagai dasar dalam penentuan pengobatan. Patogenesis merupakan perjalanan penyakit dimulai dari masuknya agen penyakit hingga menimbulkan gejala klinis. Ikan yang tergolong Cyprinidae termasuk jenis yang paling rentan terhadap berbagai infeksi parasit. Parasit 
yang menyerang ikan budidaya dapat mengakibatkan menurunnya produksi bahkan kematian pada tingkat infestasi yang tinggi. Putri dan Haditomo (2016) melaporkan adanya infestasi Gyrodactylus sebesar $26,7 \%$ di ikan lele, $13,3 \%$ di ikan mas dan $10 \%$ di ikan mas dengan gejala klinis kemerahan pada sirip dan beberapa ikan ditemukan terinfeksi jamur. Gyrodactylus merupakan ektoparasit monogenea yang menginfestasi kulit dan insang ikan air laut dan tawar. Gyrodactylosis merupakan penyakit yang disebabkan oleh infestasi Gyrodactylus. Gyrodactylosis pada ikan dapat menyebabkan lendir berlebih pada kulit, hiperplasia pada filamen insang, perubahan warna pada kulit serta kematian (Ángeles Esteban, 2012; GranoMaldonado et al., 2018; Cone and Odense, 1984).

Penelitian ini bertujuan untuk mengetahui perubahan patologi anatomi dan histopatologi insang yang diakibatkan oleh Gyrodactylus, baik diamati secara patologi anatomi maupun histopatologi.

\section{METODOLOGI}

\section{Waktu dan Tempat}

Penelitian ini dilaksanakan pada Februari 2013 dengan lokasi pengambilan sampel ikan mas dari Desa Tlogo Kecamatan Kanigoro Kabupaten Blitar Provinsi Jawa Timur, Laboratorium Pendidikan Perikanan Fakultas Perikanan dan Kelautan Universitas Airlangga dan Balai Karantina Ikan Juanda, Pengendalian Mutu dan Keamanan Hasil Perikanan Kelas I Surabaya.

\section{Materi Penelitian}

Penelitian ini menggunakan sampel berupa ikan mas (Cyprinus carpio), ektoparasit Gyrodactylus, larutan Davidson sebagai larutan fiksasi insang ikan, alkohol 70\%, 80\%, 90\%, absolut, xilena dan parafin serta pewarna Haematoxylyn Eosin.

\section{Rancangan Penelitian}

Penelitian ini dilakukan dengan pengambilan sampel di lapang dan pengamatan perubahan jaringan pada insang ikan mas (Cyprinus carpio) dengan metode deskriptif.

\section{Prosedur Kerja \\ Koleksi ektoparasit Gyrodactylus}

Sebanyak 1.440 ekor ikan mas berukuran 3-4 cm diduga terinfestasi Gyrodactylus diambil dan diamati gejala klinisnya. Sampel ikan yang telah diambil, ditransportasikan dalam plastik yang telah diisi udara untuk dilakukan pemeriksaan lebih lanjut di laboratorium.

\section{Pemeriksaan Gyrodactylus pada ikan mas}

Benih ikan yang didapat dari lapang diamati di bawah mikroskop untuk diperiksa secara natif. Ikan mas diletakkan pada object glass dan dilakukan scrapping. Kertas saring digunakan untuk menyerap air dan menipiskan spesimen. Langkah selanjutnya adalah pengamatan di bawah mikroskop dengan pembesaran 100x dan 400x. Pengambilan gambar Gyrodactylus dilakukan dengan kamera Lumix Panasonic DMC-FH2 14 Mega Pixel dengan fokus +2 .

\section{Penentuan derajat infestasi Gyrodactylus}

Penentuan derajat infestasi dilakukan berdasarkan Jensen and Johnsen (1992), yaitu derajat infestasi ringan apabila ditemukan kurang dari 100 Gyrodactylus dan derajat infestasi berat apabila ditemukan lebih dari 100 Gyrodactylus. Penentuan derajat infestasi dilakukan pada 1.440 ikan sampel dengan cara menghitung nilai intensitas Gyrodactylus yang menginfestasi ikan mas.

\section{Pengamatan histopatologi insang ikan mas}

Pengamatan histopatologi

dilakukan dengan pembuatan preparat 
histopatologi. Pembuatan preparat histopatologi dilakukan untuk mengetahui jenis kerusakan insang yang diakibatkan oleh parasit Gyrodactylus pada tingkat infestasi ringan dan berat. Pemeriksaan histopatologi sampel dilakukan terhadap insang ikan mas normal (sehat) dan insang ikan mas yang terinfestasi Gyrodactylus. Sampel insang ikan mas diproses sebagai blok parafin untuk pembuatan preparat histopatologi dan diberi pewarna H\&E. Selanjutnya preparat diperiksa secara mikroskopis untuk mengetahui perubahan dari masingmasing sampel.

Sembilan ekor ikan mas diambil untuk dilakukan pembuatan preparat histopatologi pada insang normal dan insang yang terinfestasi Gyrodactylus tingkat ringan dan berat. Tiga sampel ikan dapat digunakan dalam proses analisis tingkat jaringan (Lindenstrøm et al., 2003).

\section{Analisis Data}

Data yang diperoleh berupa data kualitatif meliputi pengamatan preparat histopatologi insang ikan mas normal dan perubahan patologi insang akibat infestasi Gyoradactylus. Data disajikan dalam bentuk gambar dan dianalisis secara deskriptif.

\section{HASIL DAN PEMBAHASAN}

Parasit Gyrodactylus melekat pada inang dengan modifikasi ujung posterior yang dikenal dengan opisthaptor. Dengan adanya perbedaan inang, maka bentuk opisthaptor pada Gyrodactylus dapat ditemukan dalam bentuk yang berbeda. Hasil pengamatan opisthaptor Gyrodactylus ditampilkan pada Gambar 1.
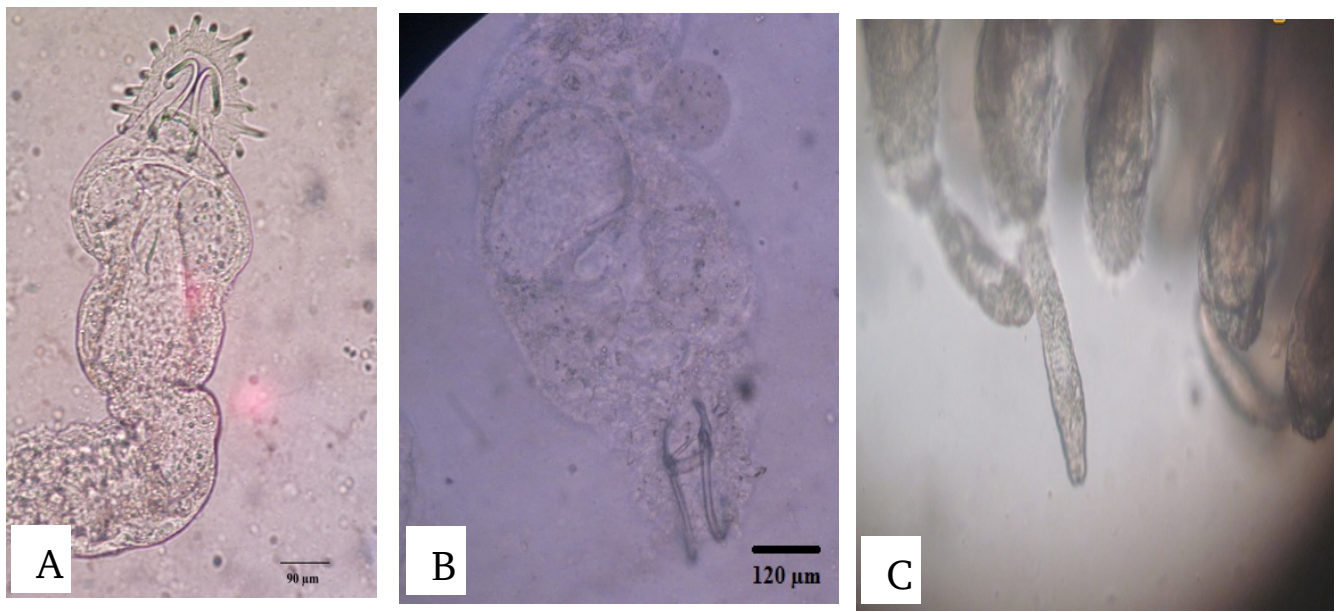

Gambar 1. Hasil pengamatan Gyrodactylus. A-C = Gyrodactylus yang ditemukan menginfestasi insang Ikan Mas. Keterangan : $1=$ Ventral Bar. $2=$ Hamuli (400x).

Berdasarkan pengamatan morfologi opisthaptor, diketahui bahwa Gyrodactylus yang ditemukan pada Gambar A memiliki ciri-ciri antara lain bagian anterolateral ventral bar cenderung pendek dan lurus, bagian hamuli (large spine) melengkung ke belakang dan bergabung pada salah satu sisinya. Gambar B menunjukkan bagian ventral bar cenderung lurus. Bagian hamuli juga cenderung lurus, tidak bergabung dengan hamuli lain, sedangkan pada Gambar C tampak infestasi Gyrodactylus pada insang ikan mas.

Hasil penentuan derajat infestasi adalah sebanyak 121 ekor ikan mas normal (tidak terinfestasi Gyrodactylus), tiga ekor ikan mas terinfestasi berat dan 1.316 ekor ikan mas terinfestasi ringan. Gyrodactylus ditemukan pada insang, kulit dan sirip ikan mas. Ikan yang diduga 
terinfestasi menunjukkan gejala klinis berupa pergerakan abnormal terutama bagian sirip ekor dan insang, ikan terlihat sering muncul di permukaan kolam dan menggesekkan tubuhnya ke permukaan kolam.
Pemeriksaan

perubahan histopatologi insang ikan mas yang terinfestasi Gyrodactylus dilakukan secara mikroskopis pada tingkat ringan dan berat. Hasil pemeriksaan perubahan patologi anatomi dan ditampilkan pada Tabel 1.

Tabel 1. Hasil pemeriksaan patologi anatomi insang ikan mas akibat infestasi Gyrodactylus.

\begin{tabular}{ll}
\hline \multicolumn{1}{c}{ Derajat Infestasi } & \multicolumn{1}{c}{ Patologi Anatomi Insang } \\
\hline Normal (Sehat) & - Insang merah segar \\
& - Susunan lamela insang rapi \\
Ringan $(<100$ Gyrodactylus/ikan) & - Insang terlihat pucat \\
& - Erosi lamela insang \\
& - Gyrodactylus hanya ditemukan pada lamela \\
& insang \\
Berat ( $>100$ Gyrodactylus/ikan $)$ & - Insang terlihat pucat \\
& - Erosi lamela insang \\
& - Produksi mukus berlebih \\
& - Gyrodactylus ditemukan hampir pada seluruh \\
& bagian insang \\
\hline
\end{tabular}

Pengamatan secara histopatologi dilakukan pada insang ikan mas normal (tidak terinfestasi Gyrodactylus) dan insang ikan mas terinfestasi Gyrodactylus tingkat ringan dan berat. Hasil pengamatan menunjukkan pada tingkat infestasi ringan dan berat kerusakan yang ditimbulkan pada insang antara lain hiperplasia, hipertrofi dan hemoragi. Sedangkan ikan mas normal menunjukkan gambaran histopatologi insang yang normal. Gado et al. (2017) juga melaporkan adanya luka erosi pada insang yang berasosiasi dengan infiltrasi leukosit akibat infestasi campuran Trematoda monogenea Gyrodactylus dan Dactylogyrus. Hiperplasia pada tepi lamela sekunder, kongesti yang berasosiasi dengan telangiectasis dan oedema juga ditemukan pada lamela insang sekunder akibat infestasi Gyrodactylus anguillae (Elgendy et al., 2016).

Pengamatan histopatologi insang normal dan insang yang terinfestasi dari lapang dapat dilihat pada Gambar 2.

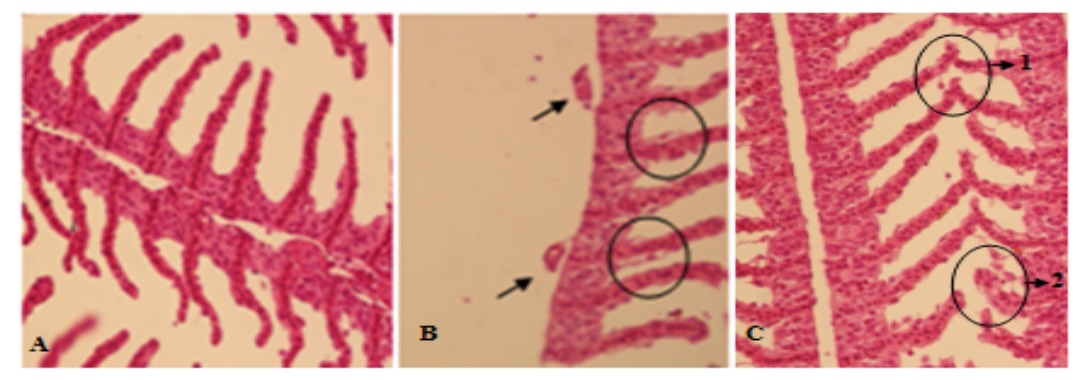

Gambar 2. Histopatologi insang ikan mas (Cyprinus carpio). A = insang ikan normal, tanpa kerusakan (400x). B = hiperplasia. Tampak adanya infestasi parasit (tanda panah). C.1) hipertrofi, 2) hemoragi. (400x. Skala Bar $=20 \mu \mathrm{m}$ ).

Variasi derajat infestasi dapat dikarenakan lama waktu infestasi Gyrodactylus pada inang yang tidak sama ataupun Gyrodactylus yang sudah terlepas dari tubuh inang. Penentuan derajat infestasi didasarkan pada Jensen and 
Johnsen (1992) yang mengemukakan bahwa derajat infestasi ringan apabila ditemukan kurang dari 100 parasit dan derajat infestasi berat apabila ditemukan lebih dari 100 parasit pada inang. Sirip kaudal, sirip pektoral, sirip anal, sirip pektoral, abdomen, epidermis kulit merupakan tempat dominasi infestasi Gyrodactylus (Mohamed et al., 2010; Barzegar et al., 2018), meski parasit ini juga ditemukan pada insang (Raissy and Ansari, 2011). Infestasi parasit ini pada inang dilakukan dengan pelekatan menggunakan opistapthor yang terletak pada posterior tubuhnya (Fitriani et al., 2019). Hansen et al. (2016) mengemukakan analisis bahwa infeksi Gyrodactylus dapat terjadi secara langsung melalui masuknya ikan-ikan impor, faktor antropogenik pada kolom perairan atau secara alami sudah terdapat Gyrodactylus pada kolam budidaya.

Terrazas (2007) mengemukakan bahwa secara alami, ikan yang terinfestasi parasit monogenea mengalami proliferasi dan hiperplasia epitel insang sebagai upaya pertahanan diri atau awal dari timbulnya respons imun. Bagian kulit dan insang dapat mengalami perubahan morfologi dan atau histopatologi ketika terkena substansi yang berbahaya atau terpengaruh pergerakan Gyrodactylus (Grano-Maldonado et al., 2018). Menurut Ozerov et al. (2010), Gyrodatylus menginfestasi ikan dan menimbulkan gangguan fungsi dengan cara mengonsumsi mukus dan merusak sel epitel ikan menggunakan hookletnya.

Analisis tingkat kerusakan melalui skoring menunjukkan adanya tingkat kerusakan berat pada preparat histopatologi insang yang terinfestasi ringan. Hal ini dapat dikarenakan akibat lama waktu infestasi Gyrodactylus pada insang ikan mas dan pengaruh kualitas air pemeliharaan (Terazas, 2007).

\section{KESIMPULAN}

Infestasi Gyrodactylus pada insang ikan mas ditemukan pada derajat infestasi ringan dan berat dengan jenis kerusakan hiperplasia, hemoragi dan hipertrofi.

\section{DAFTAR PUSTAKA}

Ángeles Esteban, M., 2012. An overview of the immunological defenses in fish skin. ISRN immunology, $853470: 29$ p.

Barzegar, M., Ebrahimzadeh Mousavi, H., Rahmati-holasoo, H., Taheri Mirghaed, A. and Bozorgnia, A., 2018. Gyrodactylus (Monogenea, Gyrodactylidae) parasite fauna of fishes in some rivers of the southern Caspian Sea basin in Mazandaran provin ce. Iran J Vet Med, 12(1). pp.35-44.

Cone, D.K. and Odense, P.H., 1984. Pathology of five species of Gyrodactylus Nordmann, 1832 (Monogenea). Canadian Journal of Zoology, 62(6), pp.1084-1088.

Elgendy, M.Y., Kenawy, A.M. and El-Deen, A.E.N., 2016. Gyrodactylus anguillae and Vibrio vulnificus infections affecting cultured eel, Anguilla anguilla. Comunicata Scientiae, 7(1), pp.1-11.

Fitriani, E.N., Arief, M. and Suprapto, H., 2019, February. Prevalence and intensity of ectoparasites in gabus fish (Channa striata) at Cangkringan Fishery Cultivation Technology Development Center, Sleman, Yogyakarta. In IOP Conference Series: Earth and Environmental Science (Vol. 236, No. 1, p. 012095). IOP Publishing.

Gado, M.S., Mahfouz, N.B., Moustafa, E.M. and El-Gawad, A.M.A., 2017. Prevalence of Monogenetic Trematodal Diseases in Some freshwater fishes at Kafr El-Sheikh Governorate. Life Science Journal, 14(8), pp.19-33.

Grano-Maldonado, M.I., RodríguezSantiago, M.A., García-Vargas, F., Nieves-Soto, M. and Soares, F., 2018. An emerging infection caused by Gyrodactylus cichlidarum Paperna, 1968 (Monogenea: 
Gyrodactylidae) associated with massive mortality on farmed tilapia Oreochromis niloticus (L.) on the Mexican Pacific coast. Latin american journal of aquatic research, 46(5), pp.961-968.

Grano-Maldonado, M., Moreno-Navas, J. and Rodriguez-Santiago, M., 2018. Transmission Strategies Used by Gyrodactylus gasterostei (Monogenea) on Its Host, the ThreeSpined Stickleback Gasterosteus aculeatus. Fishes, 3(2), p.20.

Hansen, H., Cojocaru, C.D. and Mo, T.A., 2016. Infections with Gyrodactylus spp.(Monogenea) in Romanian fish farms: Gyrodactylus salaris Malmberg, 1957 extends its range. Parasites \& vectors, 9(1), p.444.

Jensen, A.J. and Johnsen, B.O., 1992. Site specificity of Gyrodactylus salaris Malmberg, 1957 (Monogenea) on Atlantic salmon (Salmo salar L.) in the River Lakselva, northern Norway. Canadian Journal of Zoology, 70(2), pp.264-267.

Lindenstrøm, T., Buchmann, K. and Secombes, C.J., 2003. Gyrodactylus derjavini infection elicits IL-1 $\beta$ expression in rainbow trout skin. Fish \& shellfish immunology, 15(2), pp.107-115.

Mohamed, A.M., Ismaiel, M.M., Kenawy, A.M. and El-Ghany, O.A.A., 2010. Impact of Experimental Infection with Gyrodactylus Species on the Density of Skin Mucus in Fries of Catfish (Clarias gariepinus) with Emphasis on the Pathological Changes. Global Veterinaria4, pp.6773.

Molnár, K., Székely, C. and Láng, M., 2019. Field Guide to Warmwater Fish Disease in Central and Eastern Europe, The Caucasus and Central Asia. Food and Agriculture Organization of The United Nations. p.128.

Ozerov, M.Y., Lumme, J., Päkk, P., Rintamäki, P., Ziętara, M.S., Barskaya, Y., Lebedeva, D., Saadre, E., Gross, R., Primmer, C.R. and
Vasemägi, A., 2010. High Gyrodactylus salaris infection rate in triploid Atlantic salmon Salmo salar. Diseases of aquatic organisms, 91 (2), pp.129-136.

Putri, S.M. and Haditomo, A.H.C., 2016. Infestasi monogenea pada ikan konsumsi air tawar di kolam budidaya Desa Ngrajek Magelang. Journal of Aquaculture Management and Technology, 5(1), pp.162-170.

Raissy, M. and Ansari, M., 2011. Histopathological changes in the gills of naturally infected Capoeta aculeata (Cuvier and Valenciennes, 1844) with parasites. African Journal of Biotechnology, 10(68), pp.15422-15425.

Terrazas, L.I., 2007. Advances in the immunobiology of parasitic diseases. Research Signpost, 37/661 (2) : 91-109. 